\title{
Distribution of cylA, esp, asa1, hyl and gelE virulence genes among clinical isolates of Enterococcus faecium and Entrococcus faecalis
}

\author{
Elango Padmasini ${ }^{1}$, G Divya ${ }^{1}$, M Karkuzhali', R Padmaraj ${ }^{2}$, S Srivani Ramesh ${ }^{1 *}$ \\ From 2nd International Science Symposium on HIV and Infectious Diseases (HIV SCIENCE 2014) \\ Chennai, India. 30 January - 1 February 2014
}

\section{Background}

Enterococci are opportunistic pathogens causing severe urinary tract infections, surgical wound infections, bacteremia and bacterial endocarditis. Aggregation substance (asa1), hemolysin/ cytolysin ( $c y l A)$, gelatinase $($ gelE), enterococcal surface protein (esp), hyaluronidase $(h y l)$ and biofilm formation are the major virulence determinants responsible for pathogenicity of enterococci. This study was undertaken to determine virulence factors among clinical Enterococcus species by phenotypic and molecular methods.

\section{Methods}

A total of 157 enterococcal isolates obtained from various tertiary care hospitals were characterized by standard biochemical methods. Virulence factors such as gelatinase, cytolysin production by plate method and biofilm formation on 96-well microtitre plate were performed for all the isolates. The presence of $c y l A$, esp, asa1, hyl and gelE genes specific for virulence were analyzed by multiplex PCR with appropriate primers and cycling conditions.

\section{Results}

Enterococcus faecium (84/157) was the predominant species obtained, followed by E. faecalis (73/157). 72/ 157(45.85\%) strains were positive for hemolysin, $61 / 157$ (38.85\%) gelatinase, $16 / 157(10.19 \%)$ strong and 66/157 (42\%) were moderate biofilm producers phenotypically. PCR results showed, 37/157(23.56\%) cylA, 81(51.59\%) gelE, 10(6.36\%) hyl, 87(55.41\%) asa1 and 78(49.68\%) isolates were positive for esp genes. Only 25/72, 32/61,
$6 / 16$ and 7/16 isolates were phenotypically and genotypically positive for $c y l A$ +hemolysin, gelE + gelatinase, $e s p$ +biofilm and asa1 +biofilm, respectively. Interestingly, E. faecalis carried multiple virulent genes ( $>4$ genes) when compared with $E$. faecium among our study isolates.

\section{Conclusion}

Hemolysin and gelatinase were the predominant virulence factors expressed phenotypically whereas, asa1>gelE $>$ esp were the predominant genes observed. Majority of E. faecalis isolates were strong and E. faecium were moderate biofilm producers.

\section{Authors' details}

${ }^{1}$ Department of Microbiology, Dr. ALM Post Graduate Institute of Basic Medical Sciences, University of Madras, Taramani, Chennai, India. ${ }^{2}$ Department of Paediatric Nephrology, Institute of Child Health and Government Hospital for Children, Egmore, Chennai, India.

Published: 27 May 2014

doi:10.1186/1471-2334-14-S3-P32

Cite this article as: Padmasini et al:: Distribution of cylA, esp, asa1, hyl and gelE virulence genes among clinical isolates of Enterococcus faecium and Entrococcus faecalis. BMC Infectious Diseases 2014 14(Suppl 3):P32.

\footnotetext{
* Correspondence: dr.srmicro@gmail.com

'Department of Microbiology, Dr. ALM Post Graduate Institute of Basic

Medical Sciences, University of Madras, Taramani, Chennai, India

Full list of author information is available at the end of the article
} 